\title{
The Effects of Gender and Parental Education on Participation Within Post- Secondary Education in the 1970s and 1980s
}

\author{
NEIL GUPPY and KRISHNA PENDAKUR*
}

\begin{abstract}
Knowledge of factors affecting access to post secondary education is growing, but we know much less about influences shaping patterns of study within higher education. This paper explores the impact of gender and parental education on student decisions to study part-time or full-time, to choose college or university, and to enroll in different fields of study. These issues are examined using representative national samples of Canadian students from 1974-75 and 1983-84. We demonstrate that both gender and family education play decisive roles in influencing patterns of participation in higher education and that the effects of family background differ significantly between women and men.
\end{abstract}

\section{RÉSUMÉ}

Nous connaissons de mieux en mieux les facteurs qui affectent l'accès à l'éducation post-secondaire, ce qui n'est pas le cas des influences qui façonnent les programmes d'étude à l'intérieur de l'éducation supérieure. Le présent article examine les effets de l'éducation des parents et du sexe de l'étudiant sur la décision de s'inscrire comme étudiant à plein temps ou à temps partiel, sur le choix entre le collège et l'université, et sur le choix du domaine d'étude. Ces questions sont abordées en faisant appel à des échantillons nationaux représentatifs des étudiants canadiens en 1974-1975 et 1983-1984. Nous démontrons que le sexe de l'étudiant et l'éducation des parents jouent un rôle décisif dans les modèles de participation à l'éducation supérieure, et que l'historique familial exerce une influence fort différente selon qu'il s'agit d'un étudiant ou d'une étudiante.

*Anthropology and Sociology, University of British Columbia.

An earlier version of this paper was presented at the 1988 meeting of the Western Association of Anthropology and Sociology. Our thanks to Anthony Fenton for help on the earlier version. The paper has benefitted from the comments of two anonymous reviewers. 
Research focussed on equality of educational opportunity has a long history in Canada and several patterns in higher education are now well documented (for an excellent review see Pike, 1986). First, a substantial body of research has consistently replicated the finding that over the course of this century students from families of higher socio-economic status are more likely than their less privileged peers to enter post-secondary education, and especially university (e.g., Anisef, et al., 1982; Pineo and Goyder, 1988). Second, significantly more women and Francophones now enter university than was the case even 20 years ago (e.g., Fortin, 1987; Gilbert and Guppy, 1988). Third, gender-tracking within higher education continues, although some notable recent differences have occurred because of changes by women, but not by men (e.g., Gaskell, 1985; Guppy, 1988). Fourth, women and French-Canadians who have entered university tend to come disproportionately from upper socio-economic groups thereby increasing the already strong associations between access to university and socio-economic background (e.g., Guppy, et al., 1987; Harvey, 1977).

This research programme has to date emphasized who enters post-secondary education. A logical extension is to ask whether the factors affecting access also influence patterns of participation within higher education. Given the various demarcations within post-secondary education, between, for example, colleges and universities or fields of study, it is useful to examine which types of students pursue which specific patterns of participation. Research on gender-tracking within colleges or universities addresses one aspect of this work. The small studies by Harvey (1977) and Guppy (1988) also contribute by focussing on both gender and family social status.

Our purpose is to expand on these initial findings. We examine national data from the 1970s and 1980s, emphasizing changes and assessing patterns in the streaming of college and university students into specific types, and particular fields, of study. We stress differences over time by gender and parental education.

Wide-ranging changes in social values, economic conditions, and population dynamics in Canadian society might be expected to influence stratification within higher education. The stress on equal access has been a recurring theme in political circles (Anisef et al., 1982: 22-30). Combined with the economic prosperity of the post-World War II era, this emphasis on equal opportunity has been fueled by a general desire to insure that everyone has, at least in theory, a fair chance to share in this affluence. It has been an argument of "just deserts" where every individual should be provided the opportunity to prove herself or himself. With the additional stress of the baby boom generation in recent years, competition has grown more intense and this pressure also may have influenced patterns of stratification in colleges and universities.

Changes within the post-secondary environment, many attributable to the above factors, may have altered the type and stream of education pursued by members of various social groups. The expansion and diversity of post-secondary institutions in the last few decades may have opened opportunities previously not available to all. There are now more colleges and universities, more spaces in each, and more 
variation in their geographic locale. Tuition fees as a percentage of university costs have declined historically and government sponsored financial aid has expanded in the past four decades. Admission has become more flexible, courses are offered in greater variety, including night and summer school programmes, satellite campuses, and distance education, and colleges and universities have actively recruited students both through high school liaison programmes and aggressive advertising campaigns.

How these changes have affected patterns of participation within postsecondary education is unknown. Our specific project is to examine recent changes within higher education along three dimensions: time (1974-75 versus 1983-84); gender (women compared to men); and parental education (students from more and less educated families). More students, a greater proportion of whom are women, now participate in post-secondary education. Our focus is on differences in types of participation in post-secondary education as defined by registration status (full-time or part-time), institutional choice (college or university), and field of study.

\section{RESEARCH QUESTIONS}

We lack specific information on two key issues.

i) Socio-Economic Disparities Are there persistent socio-economic disparities within higher education? That is, does the socio-economic family background of a student affect types of participation in post-secondary education (as well as affecting access)? As noted above, there are reasons to be optimistic about patterns in the democratization of higher education (e.g., more spaces and a greater diversity of programmes and admitting criteria). Events of the past decade may undermine this optimism. The costs of attending college and university have recently risen, as tuition fees, the price of books and supplies, and the charges for accommodation have escalated. Information technology may also have had an unequal impact as children of more well-off families now have luxury of computing power and word processing capabilities in their own home. Finally, in periods of tighter labour markets, the power of sponsorship and networking comes to the fore as families seek to support and enrich, through personal resources and connections, the opportunities (educational and otherwise) of their children. These recent changes may have combined to make it easier for students from more prosperous families to attend postsecondary institutions relative to those from less fortunate backgrounds. Likewise, family background may also influence students' choices of post-secondary programmes.

ii) Women's Participation How has the growth of women's participation interacted with socio-economic disparities within higher education? Women now constitute the majority of post-secondary degree recipients, attaining degrees in a more diverse array of fields than ever before. However, recent shifts in the balance of women and men in specific areas of study are mainly a 
consequence of women's initiatives, since men have not substantially altered their programme choices (Gilbert and Guppy, 1988). The opportunities which women have struggled for and attained have come about through their efforts, not because male university students have changed their customs or practices.

Little is known about the women who have taken advantage of these new opportunities in higher education. What are the socio-economic backgrounds of women who now attend college and university and are branching out into fields of study previously dominated by men? There is reason to believe that these are women who come from relatively privileged backgrounds. It is often middle and upper class people who call when opportunity knocks. For example, Hout (1984) has shown that those among black American men whose mobility prospects improved most in recent times were individuals drawn from already privileged origins. For Canadian women, are the individuals participating in women's expanded participation in higher education from relatively privileged backgrounds? That is, relative to men, does family origin have a stronger influence on participation patterns in post-secondary schooling for women?

To assess aspects of stratification within higher education across dimensions of gender and family education, we examine three specific topics:

i) Full-time versus part-time study: Over the past few decades the number of students pursuing college and university courses on a part-time basis has grown. But while we know a good deal about the amount of growth, we know much less about who studies part-time. In this paper we ask whether or not part-time study has provided an avenue of participation in higher education for people from less privileged backgrounds, and if so, is this equally true for women and men.

ii) College versus university study: The advent of community colleges has expanded the opportunities for studies in higher education. Our interest is in who specifically has taken advantage of this expansion, and in whether there has been any streaming between college and university based on either gender, socio-economic origin, or their mutual interaction.

iii) Fields of study in university: The fields of study which students choose have different consequences for their careers. Professional education trains a person in a very specific set of skills whereas a liberal arts education produces a graduate with more generalized abilities. This training leads to different economic returns, be it in terms of job opportunities or earnings. Given this, which students choose which fields of study?

\section{SAMPLE AND METHODS}

In 1974-75, and then again in 1983-84, Statistics Canada undertook a representative national sample survey of students registered in Canadian colleges and universities. The 1975 survey had a $60 \%$ response rate $(\mathrm{N}=60,257)$ to a mailed questionnaire. The 1984 survey retrieved 45,181 usable questionnaires, with a response rate of $82.5 \%$. In both years the sample was stratified by type of institution (college or university), level of study (undergraduate, professional, masters, or doctorate in universities and terminal or transfer in colleges), and 
registration status (part-time or full-time). The final samples employed in our analysis are weighted to adjust for this design.

Questions on the surveys were virtually identical. Respondents were asked, among other things, to report on their gender, registration status (full or part-time), whether or not they studied at university or college, their specific field of study, and a set of questions about their family background. One important constraint is that field of study was coded differently in each survey.

For several reasons we emphasize only parental schooling, rather than a range of social status indicators. First, for both surveys, questions on family income and parental occupation had extremely high non-response which we could not assume was random among students. Second, education levels allow us to use both mother and fathers, something we could not do if we used family income, and could only do for a portion of the sample if we used occupation (given that not all mothers and fathers are in paid employment). Third, both income and occupation were measured using awkward categories, making interpretations of the results difficult. Mother's and father's education are highly correlated $(r=.54$ in 1975 and $\mathrm{r}=.58$ in 1984) and rather than arbitrarily choose one parent over another, we summed their years of schooling and in our contingency table analysis use average years recoded into three groups (less than 11 years, 11 to 13 years, and more than 13 years). Tests for alternative coding procedures, or the use of only mothers or only fathers education, produce no substantive differences in our findings.

\section{FINDINGS}

\section{i) Part-time versus Full-time Study}

We know that the proportion of students studying part-time in higher education has increased recently. Between 1974-75 and 1983-84, the surveys record a growth in the percentage of students studying part-time (3.1\% more in 1983-84), a rise roughly comparable to the general increase recorded by other Statistics Canada sources (Belanger and Omiecinski, 1987). Males were less likely than females to study part-time in $1974-75$ and the $4.4 \%$ gap between the sexes has widened so that, in $1983-84,26.1 \%$ of women in higher education studied part-time, but only $18.6 \%$ of men.

Parental education also has an important effect on whether a student is likely to study full or part-time. First, students whose parents averaged less than 11 years of schooling are more likely, in both surveys, to study part-time. Second, the proportion of students from less education families studying part-time has increased from 23.8 percent in 1974-75 to 28.6 percent in 1983-84. (For students from families with high average education, the increase has been negligible - from $15.3 \%$ to $15.7 \%$.) In short, part-time study has acted as a port of entry to higher education for many students, and particularly women from middle and working class backgrounds. 
Table 1: Percent of Students in Higher Education Studying Part-time by Gender, Family Education, and Year (in percent)

\begin{tabular}{|c|c|c|c|c|c|c|}
\hline \multirow[b]{2}{*}{$1974-75$} & \multicolumn{3}{|c|}{$\begin{array}{c}\text { Women } \\
\text { Family Education }\end{array}$} & \multicolumn{3}{|c|}{$\begin{array}{c}\text { Men } \\
\text { Family Education }\end{array}$} \\
\hline & Lo Ed & Med Ed & $\mathrm{Hi} \mathrm{Ed}$ & Lo Ed & Med Ed & $\mathrm{Hi} \mathrm{Ed}$ \\
\hline \multirow[t]{2}{*}{ Part-time } & 26.3 & 19.5 & 17.7 & 21.7 & 16.9 & 12.4 \\
\hline & \multicolumn{3}{|c|}{$\begin{array}{l}\text { tau-c }=.07 \\
\text { gamma }=.17\end{array}$} & \multicolumn{3}{|c|}{$\begin{array}{l}\operatorname{tau}-c=.08 \\
\text { gamma }=.21\end{array}$} \\
\hline \multicolumn{7}{|l|}{$1983-84$} \\
\hline Part-time & \multicolumn{3}{|c|}{$\begin{array}{l}\text { tau-c }=.13 \\
\text { gamma }=.26\end{array}$} & \multicolumn{3}{|c|}{$\begin{array}{l}\operatorname{tau}-c=.11 \\
\operatorname{gamma}=.27\end{array}$} \\
\hline
\end{tabular}

\footnotetext{
Notes: The percentages refer to the proportion of studenis studying part-time as opposed to full-time. Family Education is divided into three categories: Lo Ed average parent schooling less than 11 years; Med Ed -- average parent schooling is 11 to 13 years; $\mathrm{Hi} \mathrm{Ed}$-- average parent education is more than 13 years.
}

The combined impact of gender and parental education on part-time versus full-time studies is assessed in Table 1. First, women study part-time more frequently than men in every category of family background and, in 1983-84, 1 out of every 3 women from less educated backgrounds studied part-time. Second, in 1974-75 the influence of family education was virtually identical for men and women (percentage differences of $9.3 \%$ and $8.6 \%$ respectively), and, although in 1983-84 family background appeared to have a stronger effect, the effect was again similar for women and men. Part-time study is more frequently an alternative for women and students from less educated families.

Universities, more than colleges, were where students studied part-time in the 1970s survey. Only $9.1 \%$ of college students studied part-time in 1974-75 (and this varied only slightly by gender) whereas $25.5 \%$ of university students were studying part-time and here women $(29.3 \%)$ were more likely than men $(21.5 \%)$ to be studying part-time. This pattern held in 1983-84 as well, although the percentage of students studying part-time had increased modestly at both colleges (11.3\% - up 2.2\%) and universities (27.8\% - up 2.3\%). At university women still were more likely than men to study part-time, and the difference had widened from $7.8 \%$ in the 1970 s to $9.1 \%$ in the $1980 \mathrm{~s}$.

In summary, this section has demonstrated that part-time study is more frequently a path followed by women, especially women from families with lower education levels. Furthermore, those who study part-time are more likely to do so at university than college. There is, however, no evidence to suggest that the influence of family education differs for women and men - it is equally strong for both, and stronger in the 1980 s. 
Table 2: Percent of Students in Higher Education Studying at University by Gender, Family Education, and Year (in percent)

$$
\text { Women Men }
$$

\begin{tabular}{|c|c|c|c|c|c|c|}
\hline \multirow[b]{2}{*}{$1974-75$} & \multicolumn{3}{|c|}{ Family Education } & \multicolumn{3}{|c|}{ Family Education } \\
\hline & Lo Ed & Med Ed & $\mathrm{Hi} \mathrm{Ed}$ & Lo Ed & Med Ed & $\mathrm{Hi} \mathrm{Ed}$ \\
\hline \multirow[t]{2}{*}{ University } & 56.1 & 60.8 & 72.8 & 63.6 & 67.1 & 76.6 \\
\hline & \multicolumn{2}{|c|}{$\begin{array}{l}\text { tau-c }=.15 \\
\text { gamma }=.24\end{array}$} & \multicolumn{3}{|c|}{$\begin{array}{l}\text { tau-c }=.11 \\
\text { gamma }=.20\end{array}$} & \\
\hline \multicolumn{7}{|l|}{$1983-84$} \\
\hline \multirow[t]{2}{*}{ University } & 61.2 & 64.4 & 76.7 & 63.8 & 65.2 & 72.8 \\
\hline & \multicolumn{2}{|c|}{$\begin{array}{l}\text { tau-c }=.14 \\
\text { gamma }=.24\end{array}$} & \multicolumn{3}{|c|}{$\begin{array}{l}\text { tau-c }=.08 \\
\text { gamma }=.14\end{array}$} & \\
\hline
\end{tabular}

Notes: The percentages refer to the proportion of students studying in university as opposed to college. Family Education as defined in Table 1.

\section{ii) College versus University Study}

Differences by gender and family background also occur in the types of higher education pursued by students. In both periods the proportion of students studying at colleges was approximately one-third, and while in the earlier period women were less likely than men to go to university, this difference had vanished by 1983-84.

While gender differences have disappeared, differences by parental education were large, and remained large over time. In 1974-75, post-secondary students from more educated families were more likely to choose university $(74.8 \%)$ over college $(25.2 \%)$ than were post-secondary students from less educated backgrounds $(60.4 \%$ in universities and $39.6 \%$ in colleges). By 1983-84, the differences remained (with $74.7 \%$ and $62.5 \%$ respectively in university as opposed to college).

These gender and family education influences on college versus university study are contrasted in Table 2. In 1974-75, women are less likely than men to study at university although the difference family background makes diminishes as one ascends the socio-economic hierarchy. However, by 1983-84 a striking reversal has occurred for the group of students from the most educated families wherein women are more likely than men to study at university $(76.7 \%$ versus $72.8 \%$ respectively). For men, an increasing percentage of students at the two highest family education levels are studying at colleges, while increasing proportions of women from each family background category are studying at university in 1983-84 relative to 1974-75. (These differences are only modestly affected if we differentiate between college 'terminal' and college 'transfer' students.) As both measures of association reveal, the influence of family 
Table 3: Program of Study for University Students by Gender, Family Education, and Year (in percent)

\begin{tabular}{|c|c|c|c|c|c|c|}
\hline \multirow[b]{3}{*}{$1974-75$} & \multicolumn{3}{|c|}{ Women } & \multicolumn{3}{|c|}{ Men } \\
\hline & \multicolumn{3}{|c|}{ Family Education } & \multicolumn{3}{|c|}{ Family Education } \\
\hline & Lo Ed & Med Ed & $\mathrm{Hi} \mathrm{Ed}$ & Lo Ed & Med Ed & $\mathrm{Hi} \mathrm{Ed}$ \\
\hline \multirow[t]{2}{*}{$\begin{array}{l}\text { Undergraduate } \\
\text { Professional } \\
\text { Graduate }\end{array}$} & $\begin{array}{l}89.8 \\
1.3 \\
8.9\end{array}$ & $\begin{array}{c}88.4 \\
2.7 \\
8.9\end{array}$ & $\begin{array}{l}84.5 \\
2.7 \\
12.8\end{array}$ & $\begin{array}{c}75.1 \\
4.4 \\
20.5\end{array}$ & $\begin{array}{l}77.2 \\
6.5 \\
16.3\end{array}$ & $\begin{array}{c}73.8 \\
8.4 \\
17.8\end{array}$ \\
\hline & $100 \%$ & $100 \%$ & $100 \%$ & $100 \%$ & $100 \%$ & $100 \%$ \\
\hline \multicolumn{7}{|l|}{$1983-84$} \\
\hline \multirow[t]{2}{*}{$\begin{array}{l}\text { Undergraduate } \\
\text { Professional } \\
\text { Graduate }\end{array}$} & $\begin{array}{c}87.6 \\
3.8 \\
8.5\end{array}$ & $\begin{array}{c}87.0 \\
4.2 \\
8.9\end{array}$ & $\begin{array}{c}82.9 \\
5.8 \\
11.2\end{array}$ & $\begin{array}{c}80.9 \\
3.9 \\
15.1\end{array}$ & $\begin{array}{c}82.9 \\
3.8 \\
13.3\end{array}$ & $\begin{array}{c}80.1 \\
6.0 \\
13.9\end{array}$ \\
\hline & $100 \%$ & $100 \%$ & $100 \%$ & $100 \%$ & $100 \%$ & $100 \%$ \\
\hline
\end{tabular}

Notes: The percentages refer to the proportion of students studying different university programs. Family Education is defined in Table 1.

education on institutional choice has remained strong for women but weakened for men, demonstrating the effect we postulated initially.

\section{iii) Field of Study within University}

In this sub-section we concentrate solely on university students. We begin by assessing the influence of gender and family education on level of university study (undergraduate, professional, and graduate) and then we focus our attention even more sharply by examining specific fields of study among undergraduates.

Over the ten-year span of the two surveys, the proportion of women studying at university has increased substantially. The surveys reveal that what was a 12 percent difference in males over females in 1974-75, reversed to a slight outnumbering of women over men ( $50.4 \%$ versus $49.6 \%$ respectively) in 1983-84. Within particular levels of study the balance between the sexes had narrowed so that even at the graduate level where the $1974-75$ difference showed a $7.4 \%$ gap in favour of men, the balance in 1983-84 had narrowed to $4.6 \%$. For those studying in professional streams, there was virtually no difference in the 1983-84 survey in the percentages of men and women.

Bivariate comparisons show that once at university, family background has little influence on level of study. Only in professional programmes are students more likely to come from better educated families. In the 1974-75 survey, students from families with an average of 13 or more years of schooling were almost twice as likely to be in professional programmes relative to their peers from less educated families, a difference that decreased but did not evaporate in 1983-84. 
As Table 3 shows, these bivariate patterns change slightly once both sex and social background are considered simultaneously. Among men, family origin has very little influence on either undergraduate or graduate study, but there is a noticeable effect for students in professional programs. In 1974-75 men with more educated parents were almost twice as likely to study in professional schools ( $8.4 \%$ vs $4.4 \%$ ) but this difference had diminished considerably in the $1980 \mathrm{~s}$ $(6.0 \%$ vs $3.9 \%)$. For women, family background had a larger effect on program of study, although here too the effect had diminished by the 1980s. Notice that in graduate studies the effect of family education, while small, reverses for women and men, with women more likely to come from higher, and men from lower, family education backgrounds. In summary, gender and family education have only a modest effect on the broad programs of study in which students are enrolled at university. Nevertheless, the hypothesized effect suggesting different family origin influences for men and women is supported.

However, within programs substantial differences by sex and social background may exist. For instance, we know that women dominate in some professional programs (e.g., nursing) and men in others (e.g., engineering). To examine these differences we focus explicitly on the fields of study of university undergraduates and first professionals.

The large gender differences in field of study are well known and we do not present those findings here (see e.g., Guppy, Vellutini, and Balson, 1987). Instead we concentrate on the influence of family origins on fields of study, controlling for sex since we know already of the gender-tracking that occurs in university studies.

For most programs of study there are not big differences across family background categories. Perhaps the most striking differences in the 1974-75 survey occurred in education, where students from less educated backgrounds are more likely to be enrolled. The only program of study where there is a marked, clear difference operating in the reverse direction is for fine and applied arts where students whose parents had more education tend to predominate.

Using the categories employed in the 1974-75 study (which we cannot refine), we find little evidence of family education influences which rival the large gender differences (the latter are shown clearly by comparing the percentage of women and men in fields such as applied science or education). While the likelihood of undertaking university study is influenced by family background (as we remarked in our introduction), for those from different family education backgrounds who do go to university, there is little influence of these family origins on the type of programme students pursue.

The 1983-84 survey provides a second examination of this issue, with a different classification for fields of study. The professions are highlighted in the 1983-84 classification and so family background influences might be more apparent.

As with the 1974-75 results, parental education has small, although interesting, influences on field of study. Students with more educated parents are more likely 
Table 4: Field of Study for University Students by Gender, and Family Education (Undergraduates and First Professionals, 1974-75 -- in percent)

\begin{tabular}{|c|c|c|c|c|c|c|}
\hline & \multicolumn{3}{|c|}{$\begin{array}{l}\text { Women } \\
\text { Family Education }\end{array}$} & \multicolumn{3}{|c|}{$\begin{array}{c}\text { Men } \\
\text { Family Education }\end{array}$} \\
\hline & Lo Ed & Med Ed & $\mathrm{Hi} \mathrm{Ed}$ & Lo Ed & Med Ed & $\mathrm{Hi}$ Ed \\
\hline \multirow[t]{2}{*}{$\begin{array}{l}\text { Education } \\
\text { Fine Arts } \\
\text { Humanities } \\
\text { Social Science } \\
\text { Agr \& Bio Sci } \\
\text { Applied Sci } \\
\text { Health Profs } \\
\text { Math/Phys Sci } \\
\text { Arts \& Science }\end{array}$} & $\begin{array}{l}27.9 \\
2.8 \\
14.7 \\
27.1 \\
6.3 \\
0.8 \\
7.5 \\
3.7 \\
9.1\end{array}$ & $\begin{array}{l}21.4 \\
5.8 \\
16.4 \\
26.1 \\
7.7 \\
0.6 \\
9.8 \\
4.2 \\
8.0\end{array}$ & $\begin{array}{l}17.8 \\
7.0 \\
17.1 \\
26.0 \\
8.3 \\
1.3 \\
9.1 \\
3.3 \\
9.9\end{array}$ & $\begin{array}{c}14.4 \\
2.2 \\
9.4 \\
33.6 \\
7.8 \\
13.7 \\
3.8 \\
7.5 \\
7.6\end{array}$ & $\begin{array}{l}11.1 \\
1.8 \\
10.6 \\
37.7 \\
7.8 \\
12.3 \\
4.2 \\
8.9 \\
5.7\end{array}$ & $\begin{array}{c}7.0 \\
2.9 \\
11.8 \\
35.6 \\
9.3 \\
12.1 \\
5.1 \\
9.2 \\
7.0\end{array}$ \\
\hline & $100 \%$ & $100 \%$ & $100 \%$ & $100 \%$ & $100 \%$ & $100 \%$ \\
\hline
\end{tabular}

Notes: The percentages refer to the proportion of students in different fields of study. Family Education is defined in Table 1.

to pursue degrees in art \& science, pharmacy, medicine, and law (this pattern is similar for both women and men). A similar pattern holds in agriculture and architecture for women. Notice that in medicine, women and men are twice as likely to come from families with above average education levels (relative to students having less educated parents). The opposite is true for education and commerce, where both women and men tend to come from families with below average education levels.

Strong parental education patterns which would rival the influence of gender in effect are not detectable in these two surveys. It appears that once students go to university there is only a very minor parental education influence which carries over into the fields of study they undertake, although differences in certain professional fields are particularly noticeable.

The preceding results suggest that sex and family background have influences on the broad patterns of participation in higher education, but the parental education effect recedes once a sharper focus is undertaken (i.e., a consideration of specific fields of study within university). With respect to the broad patterns, we found support for the proposition that the effect of parental education would differ from women and men. In particular, family education was found to influence the college versus university streaming of women more than men. In addition, women in graduate school were more likely to originate from more educated families while the reverse was true for men.

Nevertheless, these patterns are documented without controls for other possible confounding factors, including differences between social categories in terms of age, marital status, parental independence, citizenship, and region. While these variables do not exhaust the list of possible confounding influences, they certainly capture most of the main factors (and we are again constrained by the survey questions themselves). We employ a multiple regression approach to assess 
Table 5: Field of Study for University Students by Gender and Family Education (Full-time Undergraduates and First Professionals, 1983-84 -- in percent)

\begin{tabular}{lcccccc} 
& \multicolumn{3}{c}{$\begin{array}{c}\text { Women } \\
\text { Family Education }\end{array}$} & & & \multicolumn{2}{c}{ Family Education } \\
\cline { 2 - 6 } & Lo Ed & Med Ed & Hi Ed & Lo Ed & Med Ed & Hi Ed \\
\hline Education & 17.5 & 17.5 & 14.6 & 10.0 & 7.7 & 5.9 \\
Engineering & 1.1 & 0.8 & 2.0 & 14.2 & 15.4 & 17.0 \\
Commerce & 15.8 & 13.1 & 10.1 & 21.6 & 19.6 & 15.3 \\
Architecture & 0.1 & 0.3 & 0.7 & 0.6 & 0.3 & 1.1 \\
Agriculture & 0.6 & 0.6 & 1.2 & 1.6 & 1.8 & 1.3 \\
Nursing & 5.7 & 4.7 & 3.6 & 0.2 & 0.0 & 0.1 \\
Pharmacy & 0.5 & 0.7 & 1.2 & 0.2 & 0.3 & 0.3 \\
Medicine & 0.8 & 0.8 & 2.0 & 1.1 & 1.8 & 2.8 \\
Dentistry & 0.2 & 0.1 & 0.2 & 0.6 & 0.3 & 0.7 \\
Law & 1.2 & 1.3 & 2.2 & 1.8 & 1.6 & 2.6 \\
Arts \& Science & 48.9 & 51.7 & 54.6 & 42.0 & 44.8 & 47.2 \\
Other & 7.7 & 8.4 & 7.5 & 6.0 & 6.4 & 5.6 \\
& $100 \%$ & $100 \%$ & $100 \%$ & $100 \%$ & $100 \%$ & $100 \%$ \\
\end{tabular}

Notes: The percentages refer to the proportion of students in different fields of study. Family Education is defined in Table 1.

whether or not the effects of sex, parental education, and in particular, their mutual interaction, retain their statistical significance in the face of controls for possible confounding variables. (Given the dependent variable is dichotomous in each case, we tested our findings using logistic regression, but choose to report the OLS regression results since the two are similar and the latter is more familiar to most readers.)

Table 6 reveals several interesting features, but the most noteworthy is that our preliminary results in Table 1 to 3 are supported. Sex and parental education always have independent effects which are statistically significant. The interaction between the two is not significant for registration status (as in Table 1), but is significant for both institutional choice and type of program (consistent with our interpretations of Tables 2 and 3). Notice also that sex is always more influential than is parental education. Controls for possible confounding influences do not alter our previous interpretations.

\section{CONCLUSIONS}

Access to higher education is strongly related to family socio-economic status. We demonstrate that parental education influences registration status and institutional choice, but has less bearing on choice of field of study within higher education. In high schools, participation in different streams or tracks is known to be strongly influenced by social status (e.g., Porter, Porter and Blishen, 1982). This effect of socio-economic status on patterns of participation does not carry over into colleges and universities. One part of the reason for this is that the socio-economic background of college and university students is far more homogeneous than is the case in high schools. 
In contrast to the patterns for social status, access to post-secondary education no longer differs for men and women, but gender does have a strong bearing on participation patterns within higher education, especially on field of study. Our multivariate results demonstrate that the influence of sex is stronger than is the effect of parents' education for each of the dependent variables explored.

First we found that both gender and family origin influence registration status. Women and students from families with lower than average education study full-time less frequently than men and students from more educated families. Second, family education has a noticeable effect on the type of institution at which students study, an influence more marked for women than men in 1983-84. Third, once a student has entered university, parental education does not have a large systematic effect on level or field of study (except perhaps in law, medicine and architecture). Gender differences persist, but only small parental education influences in selected fields exist.

The effects of parental education on institutional and programme choice (but not registration status) vary for women and men. Women pursuing university studies are more likely than their male peers to come from well-educated families. This is also true for women pursuing graduate studies who again are more likely than men to come from families with above average parental education.

The peak of the baby boom generation has now passed through post-secondary institutions and yet enrolments have not declined. The reason that student numbers have continued to rise is that the participation rate (the percentage of 18-24 years old at college or university) has increased, mainly as a result of more women entering higher education (Gilbert and Guppy, 1988). What the present research highlights is that a disproportionate number of these women (relative to men) come from better educated families.

This in turn has had consequences for other aspects of post-secondary accessibility. In the past few decades, supporters of egalitarian participation in education have pressed for the eradication of barriers to access by family social status and sex. Our results suggest that the successes of women in achieving greater access have ironically acted to further entrench the social status divisions which have long characterised post-secondary education. Much of the recent growth in post-secondary enrolments has come about as women from middle and upper class backgrounds have begun entering higher education in greater numbers.

Why this has occurred we can speculate on only briefly. At least part of the growth in female enrolments may be a consequence of a tighter or more competitive labour market facing women. Women's greater college and university enrolment may thus be directly related to the importance of education credentials in attaining jobs and promotions. A second part of the explanation may be associated with the general impact of the women's movement both with respect to attitudes toward and support for women attaining more education.

Whatever the full explanation might be, this growth has been fueled in particular by women from more educated families and it is this finding which constitutes the main contribution of our research. There are several possible explanations for 
Table 6: Multivariate Models of Posi-Secondary Student Participation (1974-75 and 1983-84): Standardized Coefficients

$1974-75$

$1983-84$

\begin{tabular}{|c|c|c|c|c|c|c|}
\hline \multirow[b]{2}{*}{$\begin{array}{l}\text { Independent } \\
\text { Variables }\end{array}$} & \\
\hline & $\begin{array}{l}\text { Partime vs } \\
\text { Fulltime }\end{array}$ & $\begin{array}{l}\text { College vs } \\
\text { University }\end{array}$ & $\begin{array}{c}\text { Undergrad } \\
\text { vs Grad }\end{array}$ & $\begin{array}{l}\text { Partime vs } \\
\text { Fulltime }\end{array}$ & $\begin{array}{l}\text { College vs } \\
\text { University }\end{array}$ & $\begin{array}{c}\text { Undergrad } \\
\text { vs Grad }\end{array}$ \\
\hline Sex & $-.063^{\bullet}$ & -.142 & -.242 & -.040 & -.115 & -.196 \\
\hline Parent's Education & $.023 *$ & $.106^{*}$ & $.085 *$ & $.027^{\circ}$ & $.114^{\circ}$ & $.080^{\bullet}$ \\
\hline Age & -.429 & $.193^{*}$ & $.146^{*}$ & $-.480 *$ & $.235 *$ & $.196 *$ \\
\hline Marital Status & $.231 *$ & .032 & -.134 & $.181 *$ & $.058^{*}$ & .038 \\
\hline Present Housing & -.032 & $.132 *$ & .063 & -.002 & $.178^{\circ}$ & .048 \\
\hline Student Loan & $-.103 *$ & -.100 & -.095 & -.106 & .001 & $-.119 \bullet$ \\
\hline Citizenship & -.010 & $-.021 \cdot$ & -.105 & $-.053^{\star}$ & -.039 & -.062 \\
\hline Atlantic & -.007 & $.051 \%$ & -.015 & -.001 & $.119 \bullet$ & -.021 \\
\hline Quebec & -.011 & -.356 & $.079^{\circ}$ & -.035 & $-.084^{*}$ & .050 \\
\hline West & .001 & -.044 & $.027^{\circ}$ & -.010 & .024 & -.017 \\
\hline SexEduc Int. & .028 & .112 & $.109 \bullet$ & .007 & $.108^{\circ}$ & .130 \\
\hline R Squared & .390 & .283 & .127 & .420 & .142 & .085 \\
\hline
\end{tabular}

Codes: Registration Status, 0 parttime, 1 fulltime; Institutional Choice, 0 college, 1 university; Type of Program, 0 undergrad, 1 postgrad; Sex, 0 male, 1 female; Marital Status, 0 married, 1 never married; Student Loan, 0 borrowed, 1 never borrowed;

Present Housing, 0 live with parents, 1 live away; Citizenship, 0 not Canadian, I Canadian;

Region, Ontario is reference category. 
why, compared to men, women are now more likely to come from families with higher levels of education. First, as more and more women compete for jobs in a tight labour market, it may be more educated parents who first recognize the importance of their daughters attaining post-secondary credentials. Second, it may be a function of resources in that less educated families can only offer financial help to one or two children, and males receive this help more often than females. Third, more educated families who have themselves experienced post-secondary education may have more respect for colleges and universities and therefore be more encouraging for all of their children to attend.

These are tentative hypotheses requiring further research. New research initiatives should also consider alternative ways of recasting our parental education measure, and incorporating other indicators of socio-economic status. When a third wave of the survey of post-secondary education is undertaken, inclusion of more powerful measures to examine stratification patterns within higher education would be beneficial for the accessibility research programme.

\section{REFERENCES}

Anisef, P., Okihiro, N. \& James, C. (1982). The Pursuit of Equality: Evaluating and Monitoring Accessibility to Post-Secondary Education in Ontario Toronto: Ministry of Education.

Belanger, R. \& Omiecinski. T. (1987). Part-time University Enrolment. Canadian Social Trends Summer, 22-25.

Fortin, M. (1987). Accessibility to and Participation in the Post-Secondary Education System in Canada. Paper presented to the National Forum on Post-Secondary Education, Saskatoon, pp. 1-19.

Gaskell, J. (1987). Women and Education: Branching Out. Towards Equity. Ottawa: Economic Council of Canada.

Gilbert, S. \& Guppy, N. (1988). Trends in Participation in Higher Education by Gender. J. Curtis et al. (eds) Social lnequality in Canada: Patterns, Problems, Policies. Toronto: Prentice Hall.

Guppy, N. (1984). Access to Higher Education in Canada. Canadian Journal of Higher Education XIV(3), 79.93.

Guppy, N. (1985). Education Under Siege: Financing and Accessibility in B.C. Universities. Canadian Journal of Sociology 10(3), 295-308.

Guppy, N. (1988). Accessibility to Post-Secondary Education: New Trend Data. CAUT Bulletin $35(6), 15-16$.

Guppy, N., Mikicich, P. \& Pendakur, R. (1984). Changing Patterns of Educational Inequality in Canada. Canadian Journal of Sociology 9(3), 119-131.

Guppy, N., Vellutini, S. \& Balson, D. (1987). Women and Higher Education in Canadian Society. In J. Gaskell and A. McLaren (eds.) Women and Education: A Canadian Perspective Calgary: Detselig.

Harvey, E. (1977). Accessibility to Post-Secondary Education. University Affairs October, 10-11.

Hout, M. (1984). Occupational Mobility of Black Men: 1962-1973. American Sociological Review 49

Pike, R. (1982). Social Goals and Economic Constraints: Issues of Accessibility to Canadian Higher Education During the 1980s. Education Research and Perspectives December, 1-39.

Pineo, P. \& Goyder, J. (1988). Growth of the Canadian Education System: An Analysis of Transitional Probabilities. Canadian Journal of Higher Education, 18, 2: 37-55.

Porter, J., Porter, M. \& Blishen, B. (1982). Stations and Callings. Toronto: Methuen. 